\title{
Comparative Study of Interactional Metadiscourse Markers in the Discussion Section of Soft and Hard Science Research Articles: Hedges and Boosters in Focus
}

\author{
Maryam Farnia*, Sara Gerami \\ Department of English Language and Literature, Payame Noor University, Iran
}

Received on: 10-3-2020

Accepted on: 28-7-2020

\begin{abstract}
The aim of this descriptive analytical study was to examine research articles discussion sections from four disciplines to measure the functions and frequencies of hedges and boosters. To this end, scholarly research articles were randomly selected from leading and reputable journals in mechanical and industrial engineering as representatives of hard science disciplines and management and psychology as representatives of soft science disciplines. The size of the corpus in each discipline was around 17000 words. The data were analyzed in light of Hyland's (2005) model of interactional metadiscourse for hedges and boosters devices. Results of descriptive and inferential statistics showed that the use of hedges was significantly more in soft science disciples while boosters were overused in hard science disciplines, corresponding to the fact that by virtue of being less personal and more objective, hard sciences are represented through more frequent use of boosters than hedges to express facts. On the other hand, soft sciences are influenced by their subjectivity which results in higher frequencies of hedges. The findings of this study have implications for English for Academic/Specific purposes courses.
\end{abstract}

Keywords: Discussion section, Research article, Metadiscourse, Booster, Hedge.

\section{Introduction}

Distinctive genre in academic writing causes the use of specific styles and rules which are objective and formal. This particular style needs precise word choice in order to gain academic acceptance because it is written for scholarly experts and investigates an issue in a specific discipline. Hyland (2013) points out that many students around the world need to gain fluency in the conventions of academic writing in English to flourish their learning and careers. According to Hyland (2013: 54), "student writing is now often a key area in continuing professional development programs." As a result, the quality of students' writings is mostly related to their proficiency in English rather than other factors; an issue which needs more consideration in educational systems.

Metadiscourse, as defined by Hyland (2005, 37), refers to "the self-reflective expressions used to negotiate interactional meanings in a text, assisting the writer (or speaker) to express a viewpoint and engage with readers as members of a particular community." The literature is replete with ongoing studies on metadiscourse in academic writing (e.g., $\mathrm{Li}$ and $\mathrm{Xu}, 2020$; Uba, 2020, Wei and Duan, 2019; to name

๑ 2021 JJMLL Publishers/Yarmouk University. All Rights Reserved,

${ }^{*}$ Doi: https://doi.org/ 10.47012/jjmll.13.2.5

* Corresponding Author: mfarniair@gmail.com

* The research reported in this paper was funded by Payame Noor University, Iran, for which we are grateful. 


\section{Farnia, Gerami}

but a few). These studies either attended to interactional resources or the devices the writers used to manage the information they carry in text in order to show their indented message (Hyland, 2004a), or the studies emphasized the use of interactional resources which "focus on the participants of the interaction and seek to display the writers persona and a tenor consistent with the norms of disciplinary community" (Hyland 2004a, 139).

As a subcategory of interactional metadiscourse, hedges and boosters are employed to realize a communicative strategy in which hedges provide an opportunity to manipulate a text in a manner that is not easy for the reader to evaluate the truth value of what is being expressed and the one responsible for it (Markkanen and Schröder, 1997), while boosters leave little room for the reader to have their own interpretations and are employed to develop interpersonal solidarity with the reader (Hyland 1998). The findings of previous studies showed cross-cultural and cross-disciplinary differences in the use of hedges and boosters in academic discourse (e.g., Hu and Cao, 2011; Siami and Abdi, 2012). Several studies investigated the use of metadiscourse markers cross-linguistically (e.g., research articles in English and Chinese by Kim and Lim 2013; Mu, Zhang, Ehrich and Hong, 2015; in English and Arabic by Alotaibi, 2015; Sultan, 2011, English and Persian by Karimi, Maleki and Farnia, 2017; Yazdani, Sharifi and Elyassi, 2014), or cross-disciplinary (e.g., Aluthman, 2018; Khedri, Heng and Hoon, 2013), or a certain section of research article (e.g., abstract section by Liu and Huang ,2017; introduction sections by Farzannia and Farnia, 2016; Kim and Lim, 2013; Sorahi and Shabani, 2016; results and discussion by Lee and Casal, 2017). Moreover, while previous research has explored differences in research articles published in hard and soft science disciplines in terms of generic differences (e.g., Alhuqbani, 2013), or evaluative language (e.g., Farnia, Saeedi and Atae,i 2020), no study has investigated the use of boosters and hedges in the discussion sections across journals in hard and soft disciplines.

The discussion section of research articles is significantly important since it offers "study's contribution by highlighting the major findings, interpreting them in light of previous research, presenting rational justifications, and deploying the author's original views in form of academically rich arguments" (Swales and Feak, 2004, cited in Hashemi and Moghadam,, 2016:2). Therefore, this comparative study was conducted to explore the use of such metadiscourse markers in the discussion sections of articles published in hard science and soft science disciplines. To this aim, the study sought answers to the following research questions:

1. What are the frequencies of hedges and boosters in the soft and hard science corpora?

2. Is there any significant cross-disciplinary difference in the use of boosters and hedges?

\section{Review of the Literature}

\subsection{What is Metadiscourse?}

Metadiscourse refers to the linguistic resources the writers used to express their stance in the paper both to the reader and the content (Hyland 2000). To have an effective writing, the authors should take the reader's "objection, background knowledge, rhetorical expectations and processing needs into account" (Hyland and Jiang 2020, 138). In other words, the focus of metadiscourse is on how writers express themselves through their discourse in the text and to the audience. 
Comparative Study of Interactional Metadiscourse Markers in the Discussion Section of Soft and Hard Science Research Articles: Hedges and Boosters in Focus

As one of the most comprehensive model of interpersonality, metadiscourse (Fu and Hyland, 2014), metadiscourse appeared in Applied Linguistics about thirty years ago (Vande Kopple, 1985). There are generally two types of metadiscourse: interactive (textual) and interactional (interpersonal) (Hyland, 2004b; Hyland and Tse 2004) presented in Table 1.

Table 1: A model of metadiscourse in academic texts (adopted from Hyland 2015).

\begin{tabular}{|c|c|c|}
\hline Category & Function & Examples \\
\hline Interactive & Help to guide reader through the text & \\
\hline \multicolumn{3}{|l|}{ Resources } \\
\hline Transitions & $\begin{array}{l}\text { express semantic relation between main } \\
\text { clauses }\end{array}$ & in addition / but / thus / and \\
\hline Frame markers & $\begin{array}{l}\text { refer to discourse acts, sequences, or text } \\
\text { stages }\end{array}$ & $\begin{array}{l}\text { finally / to conclude / my purpose } \\
\text { is }\end{array}$ \\
\hline Endophoric markers & refer to information in other parts of the text & noted above / see Fig / in section 2 \\
\hline Evidentials & $\begin{array}{l}\text { refer to source of information from other } \\
\text { texts }\end{array}$ & $\begin{array}{l}\text { according to } \mathrm{X} /(\mathrm{Y}, 1990) / \mathrm{Z} \\
\text { states }\end{array}$ \\
\hline Code glosses & $\begin{array}{l}\text { help readers grasp meanings of ideational } \\
\text { material }\end{array}$ & $\begin{array}{l}\text { namely /e.g./such as / in other } \\
\text { words }\end{array}$ \\
\hline $\begin{array}{l}\text { Interactional } \\
\text { resources }\end{array}$ & Involve the reader in the argument & \\
\hline Hedges & $\begin{array}{l}\text { withhold writer's full commitment to } \\
\text { proposition }\end{array}$ & might / perhaps / possible /about \\
\hline Boosters & $\begin{array}{l}\text { emphasize force or writer's certainty in } \\
\text { proposition }\end{array}$ & in fact / definitely / it is clear that \\
\hline Attitude markers & express writer's attitude to proposition & $\begin{array}{l}\text { unfortunately / I agree / } \\
\text { surprisingly }\end{array}$ \\
\hline $\begin{array}{l}\text { Engagement } \\
\text { markers }\end{array}$ & $\begin{array}{l}\text { explicitly refer to or build relationship with } \\
\text { reader }\end{array}$ & $\begin{array}{l}\text { consider / note that / you can see } \\
\text { that }\end{array}$ \\
\hline Self-mentions & explicit reference to author(s) & $\mathrm{I} / \mathrm{we} / \mathrm{my} /$ our \\
\hline
\end{tabular}

The function of the interactive metadiscourse is to display "topic shift, signaling sequences, crossreferencing, connecting ideas, and so on", while the function of the interpersonal metadiscourse is to highlight the authors 'attitude by the use of devices such as hedges, boosters, self-reference, and so on (Hyland and Tse 2004, 158), generally known as appraisal (Martin 2001) or evaluation (Hunston and Thompson 2001). According to Hyland (2015), there is no one to one correspondence between a form and its function in a text, rather analyzing a text begins with attending to its linguistic form, and then examining its relevant function in the same text.

The interactional metadiscourse has been used as a framework to analyze the linguistic resources of intersubjectivity, and is interchangeably used with other headings such as modality, evidentiality, hedging, enabling the writers to articulate their view point in the text by voicing their stance and expecting readers' response to it (Fu and Hyland 2014). As Table 1 shows, interactional metadiscourse consists of five categories of hedges, boosters, attitude markers, engagement markers and self-mentions.

While the use of interpersonal/interactional metadiscourse, including boosters and hedges, allows authorial participation as a central aspect of rhetorical feature of academic writing (Hyland 2005), they are not largely ignored in English for academic purposes textbooks in which the prominence is given to how referential information is generally conveyed (Hyland 2000). The purpose of this paper is to examine how writers of different disciplines make use of these features in their academic writing. 
Farnia, Gerami

\subsection{Hedges and Boosters in Academic Writing}

Hyland (1998) claims that expressing doubt and certainty in academic writing is important. The writers need to strike a balance between using certainty and uncertainty statements, which is called hedging and boosting. There has been a surge of interest in hedges and boosters in academic discourse as they can create rhetorical and interactive tenor in a way that implies both epistemic and affective meanings. That is to say, hedges and boosters can express writers' confidence in conveying facts in addition to showing respect and modesty to their audience and colleagues. As such, successful academic discourse must maintain a balance between these two. As stated by Hyland (2004c, 87), "hedges and boosters are communicative strategies for increasing or reducing the force of statements." Hyland (1998, 1) is also of the opinion that, "hedges and boosters are communicating strategies for increasing or reducing the force of statements." Hence, the use of hedges and boosters expresses epistemic and affective meanings. Strong claims are represented by boosters in order to express facts and true statements, but softer claims are expressed by hedges to show subjective views. Indeed, academic acceptance is in part dependent upon proper expression of doubt and certainty in using hedges and boosters (Hyland 2000). Therefore, successful academic writing needs both proper display of modesty by using hedges and appropriate use of boosters in expression of conviction. In this regard, hedges and boosters are related to ideational and interpersonal meanings (Halliday 1994) reflecting the writers' opinion and factual statements, too.

As complex devices which carry different functions in academic writing, hedges and boosters are regulated by "both general rules of communication and the norms and practices of particular disciplines" (Farrokhi and Emami 2008, 93). Therefore, second language learners must be taught to correctly interpret the function of an array of hedges and boosters as lexical items which are used to express writers' degree of certainty in an academic text.

\subsection{Previous Empirical Studies}

Previous studies examined different aspects of hedging and boosting in texts. Farrokhi and Emami (2008) evaluated the use of hedges and boosters in 20 research articles of electrical engineering and applied linguistics in four sections of a research article (i.e., abstract, introduction, discussion, and conclusion). The results suggested that hedges and boosters have more occurrences in applied linguistics articles than electrical engineering articles. In another study, Takimoto (2015) examined the function and frequency of boosters and hedges in the research articles of eight disciplines in the three fields of cultural sciences (e.g., linguistics and philosophy), social sciences (e.g., marketing and sociology), and natural science (e.g., physics, electrical engineering, mechanical engineering, and chemistry). The results showed higher occurrences of hedges and boosters in philosophy articles. It was deduced that humanities and

social sciences authors used more hedges and boosters and opted for subjectivity; their counterparts in natural sciences were more objectively-oriented and thus used fewer hedges and boosters.

Hyland and Tse's (2004) new model of using metadiscourse in writing was developed based on 240 master and doctorial postgraduate dissertations. The findings indicated that both in master and doctorial 
Comparative Study of Interactional Metadiscourse Markers in the Discussion Section of Soft and Hard Science Research Articles: Hedges and Boosters in Focus

dissertations the occurrence of hedges was more than boosters. Hyland and Tse (2004) claim that hedges with $41 \%$ occurrence were the most frequent subcategories of interactional metadiscourse. According to Hyland and Tse (2004), this indicated that in academic writing, a fact is distinguished from opinion and writers need to evaluate their assertions in persuasive ways and with appropriate caution.

A comparison of hedges and boosters showed that they are densely used in the discussion section (Takimoto 2015). Discussion section is an important part of a research article where the writers share their findings with the readers and contribute their knowledge to the existing literature. Moreover, writers explain and justify their findings in this section (Hagin 2009). Writing an effective discussion is believed to be particularly demanding for students because “... it involves complex causal, conditional and purposive argument; this argument guides the reader from acceptance of the relatively uncontroversial data to acceptance of the writer's knowledge claim" (Parkinson 2011, 164). Therefore, a thorough examination of the discussion section across diverse disciplines could help explain how writers get involved in a text and involve the reader. In light of the aforementioned theoretical rationale and empirical evidence, this study attempted to examine the occurrence of hedges and boosters in the discussion section of two hard and soft science disciplines.

\section{Methodology}

The corpus consisted of two groups of journals representing soft science and hard science disciplines randomly selected from the journals indexed in Science Direct as one of the world's largest sources of scientific data. Sixty research articles discussion sections from two engineering disciplines, i.e., mechanical and industrial, as representatives of hard science journals, and two disciplines in social sciences and humanities, i.e., psychology and management as representatives of soft science journals were randomly selected from the body of journals published within the span of 2017 to 2018. The corpora were fairly comparable in terms of length (i.e., about 17,000 words in each of the four disciplines). The journals are listed in Table 1.

Table 1: Corpus information in hard and soft disciplines.

\begin{tabular}{cllc}
\hline Discipline & \multicolumn{1}{c}{ Major } & \multicolumn{1}{c}{ Journals } & No \\
\hline & Mechanical & European Journal of Mechanics/a solids & 5 \\
& Engineering & Engineering fracture mechanics & 2 \\
& & Archives of civil and mechanical engineering & 2 \\
& & Extreme mechanics letters & 1 \\
& Journal of mechanics and physics of solids & 1 \\
& & Mechanical systems and signal processing & 3 \\
Hard science & Industrial & Theoretical and applied fracture mechanics & 1 \\
discipline & Engineering & Computer and Industrial Engineering & 4 \\
& & International Journal of Industrial Ergonomics & 2 \\
& & Computers in Industry & 3 \\
& & Process Safety and Environmental Protection & 1 \\
& & Journal of Process Control & 2 \\
& & Journal of Operations Management & 1 \\
& & Additive Manufacturing & 1 \\
& Scientific Report & 1 \\
\hline
\end{tabular}


Farnia, Gerami

\begin{tabular}{llll}
\hline Discipline & \multicolumn{1}{c}{ Major } & \multicolumn{1}{c}{ Journals } & No \\
\hline & Psychological & Cognitive and Behavioral Practice & 1 \\
& & 3 \\
& & European Journal of Trauma And Dissociation & 1 \\
& Brain and Language & 1 \\
& Behavior Research and Therapy & 1 \\
& The European Journal of Psychology Applied to Legal & 1 \\
& Context & 4 \\
Soft science & Mental Health and Prevention & 2 \\
discipline & Behavior Therapy & 1 \\
& The Arts in Psychology & 1 \\
& International Journal of Clinical And Health Psychology & 5 \\
& Journal of Co-Operative Organization and Management & 3 \\
& International Journal of Project Management & 3 \\
& Journal of Engineering and Technology Management & 2 \\
& European Journal of Management & 1 \\
\hline
\end{tabular}

To collect the required data, the journals were randomly selected from research articles published in four disciplines representing soft and hard sciences and indexed in Science Direct. For the purpose of this study, only the discussion section was considered for analysis. The discussion section of each discipline constituted one corpus. Each line was read and the hedging and boosting devices were examined based on Hyland's (2005) metadiscourse model. It needs to be pointed out that as the functions of linguistic forms cannot be identified separate from their context (Holms 1990), to ensure a reliable and exact interpretation, each device was studied and interpreted in its surrounding context. Therefore, those devices which were identified as hedges and boosters were included in the data analysis. To minimize the level of subjective judgment, the encoded data sample was reviewed by a third coder for a consistency check. For this purpose, the third coder analyzed $10 \%$ of the data independently and the categories were checked among coders to ensure agreement. The coders discussed the cases of disagreement, finally reaching $95 \%$ of agreement in the coded classification.

\section{Results}

Table 2 shows the results of the overall analysis of the data. In response to the research question, "What are the frequencies of hedges and boosters in the soft and hard science corpora?" The findings show that the overall use of hedges in the soft science discipline is more than the hard science discipline. However, the use of boosters in the hard science discipline is more than the soft science discipline.

Table 2: The Distribution of Hedges and Boosters in each discipline.

\begin{tabular}{|c|c|c|c|c|c|c|c|c|c|c|}
\hline & \multicolumn{5}{|c|}{ Hard Science } & \multicolumn{5}{|c|}{ Soft Science } \\
\hline & \multicolumn{2}{|c|}{$\begin{array}{l}\text { Mechanical } \\
\text { engineering }\end{array}$} & \multicolumn{2}{|c|}{$\begin{array}{l}\text { Industrial } \\
\text { engineering }\end{array}$} & & \multicolumn{2}{|c|}{ Psychology } & \multicolumn{2}{|c|}{ Management } & \\
\hline & $\mathrm{F}$ & $\%$ & $\mathrm{~F}$ & $\%$ & & $\mathrm{~F}$ & $\%$ & $\mathrm{~F}$ & $\%$ & \\
\hline Hedges & 340 & 54.15 & 288 & 45.85 & 628 & 440 & 53.40 & 374 & 46.60 & 814 \\
\hline Boosters & 197 & 49.40 & 202 & 50.60 & 399 & 172 & 59.10 & 119 & 40.90 & 291 \\
\hline
\end{tabular}

Table 3 presents the overall distribution of boosters and hedges in the two disciplines. As shown in the table, there is a significant difference in the use of hedge and boosters in the two corpora. In other words, the authors in the soft science disciplines used significantly more hedges $(p<0.05$, sig. $=0.00)$ 
Comparative Study of Interactional Metadiscourse Markers in the Discussion Section of Soft and Hard Science Research Articles: Hedges and Boosters in Focus

than authors in the hard discipline. On the other hand, authors in hard science disciplines used significantly more hedges $(p<0.05$, sig. $=0.00)$ than those in soft sciences.

Table 3: The distribution of boosters and hedges across the corpora.

\begin{tabular}{llllllll}
\hline \multicolumn{1}{c}{ Metadiscourse type } & \multicolumn{2}{c}{ Hard discipline } & \multicolumn{2}{c}{ Soft discipline } & & X & Sig. \\
\cline { 1 - 5 } Hedges & $\mathrm{F}$ & $\%$ & $\mathrm{~F}$ & $\%$ & & df & 0.00 \\
Boosters & 628 & 61.15 & 814 & 73.90 & 88.2189 & 1 & 0.00 \\
\hline
\end{tabular}

Table 4 presents the hedges found in the management and psychology journals as representatives of soft science disciplines. As shown in Table 4, the most frequent hedges in management research article discussion sections are could $(\mathrm{n}=41)$, may $(\mathrm{n}=37)$, suggest $(\mathrm{n}=33)$, and might, most, seem, and should $(\mathrm{n}=16)$, while the most frequent hedges in the discussion section of psychology research articles are may $(=71)$, would $(\mathrm{n}=36)$, suggest $(\mathrm{n}=33)$, possible(ly) $(\mathrm{n}=30)$, most $(\mathrm{n}=20)$, and should and could $(\mathrm{n}=18)$. On the whole, authors of psychology research articles used a greater number of hedges in discussing their results compared to authors in management research articles. What is common in the two corpora, however, is the occurrence of could, suggest, may, and might as the four most frequent hedges spotted in the two groups of soft science journals.

Table 4: Distribution of Hedges in Soft Discipline Research Articles.

\begin{tabular}{|c|c|c|c|c|c|}
\hline \multicolumn{3}{|c|}{ Management } & \multicolumn{3}{|c|}{ Psychology } \\
\hline Hedges & Frequency & Percentage & Hedges & Frequency & Percentage \\
\hline Could & 41 & 10.6 & May & 71 & 16.1 \\
\hline May & 37 & 9.6 & Would & 36 & 8.1 \\
\hline Suggest & 33 & 8.5 & Suggest & 33 & 7.5 \\
\hline Might & 16 & 4.1 & Might & 32 & 7.2 \\
\hline Most & 16 & 4.1 & Possible(ly) & 30 & 6.8 \\
\hline Seem & 16 & 4.1 & Most & 20 & 4.5 \\
\hline Should & 16 & 4.1 & Should & 18 & 4.0 \\
\hline Possible(ly) & 14 & 3.6 & Could & 18 & 4.0 \\
\hline (general)sense & 13 & 3.3 & indicate & 16 & 3.6 \\
\hline Would & 12 & 3.1 & Appear & 11 & 2.5 \\
\hline Often & 11 & 2.8 & Predict & 11 & 2.5 \\
\hline Appear & 10 & 2.6 & Consistent with & 10 & 2.2 \\
\hline Perhaps & 10 & 2.6 & Seem & 10 & 2.2 \\
\hline Usually & 10 & 2.6 & Often & 9 & 2.0 \\
\hline Likely & 9 & 2.3 & Seen(as) & 7 & 1.5 \\
\hline (in)general & 8 & 2.0 & Likely & 6 & 1.3 \\
\hline Perceive & 8 & 2.0 & Unclear & 5 & 1.1 \\
\hline Indicate & 7 & 1.8 & Generally & 5 & 1.1 \\
\hline Implication & 7 & 1.8 & (in)general & 5 & 1.1 \\
\hline Consistent with & 7 & 1.8 & Typically & 5 & 1.1 \\
\hline Propose & 7 & 1.8 & possibility & 4 & 0.9 \\
\hline Tendency & 6 & 1.5 & Rather & 4 & 0.9 \\
\hline Around & 5 & 1.3 & Somewhat & 4 & 0.9 \\
\hline Mainly & 4 & 1.0 & Implication & 4 & 0.9 \\
\hline Sometimes & 4 & 1.0 & (not)always & 3 & 0.6 \\
\hline Tend & 4 & 1.0 & assume & 3 & 0.6 \\
\hline Argue & 3 & 0.7 & prediction & 3 & 0.6 \\
\hline Predict & 3 & 0.7 & Probable(ly) & 3 & 0.6 \\
\hline Largely & 3 & 0.7 & Relatively & 3 & 0.6 \\
\hline (not)always & 2 & 0.5 & Tend & 3 & 0.6 \\
\hline Estimate & 2 & 0.5 & Frequently & 3 & 0.6 \\
\hline
\end{tabular}


Farnia, Gerami

\begin{tabular}{|c|c|c|c|c|c|}
\hline \multicolumn{3}{|c|}{ Management } & \multicolumn{3}{|c|}{ Psychology } \\
\hline Hedges & Frequency & Percentage & Hedges & Frequency & Percentage \\
\hline Frequently & 2 & 0.5 & Interpret & 3 & 0.6 \\
\hline Probability & 2 & 0.5 & Mainly & 3 & 0.6 \\
\hline Rather & 2 & 0.5 & Not necessarily & 3 & 0.6 \\
\hline Relatively & 2 & 0.5 & almost & 2 & 0.4 \\
\hline Seen (as) & 2 & 0.5 & perhaps & 2 & 0.4 \\
\hline Typically & 2 & 0.5 & Presume & 2 & 0.4 \\
\hline Unclear & 2 & 0.5 & Shouldn't & 2 & 0.4 \\
\hline Apparently & 1 & 0.2 & Sometimes & 2 & 0.4 \\
\hline Assume & 1 & 0.2 & Speculate & 2 & 0.4 \\
\hline Generally & 1 & 0.2 & Usually & 2 & 0.4 \\
\hline Maybe & 1 & 0.2 & Maybe & 2 & 0.4 \\
\hline Not necessarily & 1 & 0.2 & approximately & 1 & 0.2 \\
\hline Normally & 1 & 0.2 & plausible & 1 & 0.2 \\
\hline Partially & 1 & 0.2 & around & 1 & 0.2 \\
\hline Plausible & 1 & 0.2 & about & 1 & 0.2 \\
\hline Possibility & 1 & 0.2 & predominantly & 1 & 0.2 \\
\hline Probable(ly) & 1 & 0.2 & partially & 1 & 0.2 \\
\hline Rare(ly) & 1 & 0.2 & Presumably & 1 & 0.2 \\
\hline Somewhat & 1 & 0.2 & Probability & 1 & 0.2 \\
\hline Speculate & 1 & 0.2 & Propose & 1 & 0.2 \\
\hline Unlikely & 1 & 0.2 & Quite & 1 & 0.2 \\
\hline Infer & 1 & 0.2 & Rare(ly) & 1 & 0.2 \\
\hline \multirow[t]{9}{*}{ Interpret } & 1 & 0.2 & Seeming(ly) & 1 & 0.2 \\
\hline & & & Suppose & 1 & 0.2 \\
\hline & & & Tendency & 1 & 0.2 \\
\hline & & & Theoretically & 1 & 0.2 \\
\hline & & & My/our belief & 1 & 0.2 \\
\hline & & & Conceivably & 1 & 0.2 \\
\hline & & & Discern & 1 & 0.2 \\
\hline & & & Estimate & 1 & 0.2 \\
\hline & & & Normally & 1 & 0.2 \\
\hline Total & 374 & $100 \%$ & Total & 440 & $100 \%$ \\
\hline
\end{tabular}

Table 5 displays the boosters found in management and psychology journals as representatives of soft science disciplines. As shown in Table 5, the most frequently used boosters in the management corpus are show $(\mathrm{n}=36)$, confirm $(\mathrm{n}=10)$, the fact that $(\mathrm{n}=9)$, and demonstrate, expect and clear(ly) $(\mathrm{n}=7)$, while the most frequent boosters found in the discussion section of psychology research articles are show $(\mathrm{n}=50)$, demonstrate $(\mathrm{n}=18)$, clear $($ ly) and at least $(\mathrm{n}=12)$, particularly $(\mathrm{n}=10)$, and confirm, indeed and more than $(\mathrm{n}=7)$. The findings show that the verb show was the most frequent booster in the two groups of journals. 
Comparative Study of Interactional Metadiscourse Markers in the Discussion Section of Soft and Hard Science Research Articles: Hedges and Boosters in Focus

Table 5: Distribution of Boosters in Soft discipline Research Articles.

\begin{tabular}{|c|c|c|c|c|c|}
\hline \multicolumn{3}{|c|}{ Management } & \multicolumn{3}{|c|}{ Psychology } \\
\hline Boosters & $\mathrm{F}$ & $\%$ & Boosters & $\mathrm{F}$ & $\%$ \\
\hline Show & 36 & 30 & Show & 50 & 29.0 \\
\hline Confirm & 10 & 8.4 & Demonstrate & 18 & 10.4 \\
\hline The fact that & 9 & 7.5 & Clear(ly) & 12 & 6.9 \\
\hline Particularly & 8 & 6.7 & (At) least & 12 & 6.9 \\
\hline Demonstrate & 7 & 5.8 & Particularly & 10 & 5.8 \\
\hline Expect & 7 & 5.8 & Confirm & 7 & 4.0 \\
\hline Clear(ly) & 7 & 5.8 & Indeed & 7 & 4.0 \\
\hline Perceive & 6 & 5.0 & More than & 7 & 4.0 \\
\hline Determine & 5 & 4.2 & True & 6 & 3.4 \\
\hline Indeed & 3 & 2.5 & The fact that & 5 & 2.9 \\
\hline More than & 3 & 2.5 & Always & 4 & 2.3 \\
\hline Always & 2 & 1.6 & In fact & 3 & 1.7 \\
\hline Evidence & 2 & 1.6 & Certainly & 3 & 1.7 \\
\hline Must & 2 & 1.6 & Never & 3 & 1.7 \\
\hline True & 2 & 1.6 & Prove & 3 & 1.7 \\
\hline Conclusive(ly) & 1 & 0.8 & Conclusive(ly) & 2 & 1.1 \\
\hline Of course & 1 & 0.8 & Conclude & 2 & 1.1 \\
\hline Is essential & 1 & 0.8 & Obvious(ly) & 2 & 1.1 \\
\hline Well-known & 1 & 0.8 & (without) question & 2 & 1.1 \\
\hline In fact & 1 & 0.8 & Quite & 2 & 1.1 \\
\hline Actually & 1 & 0.8 & Determine & 1 & 0.5 \\
\hline Inevitable(ly) & 1 & 0.8 & Expect & 1 & 0.5 \\
\hline Conclude & 1 & 0.8 & Given that & 1 & 0.5 \\
\hline Never & 1 & 0.8 & Impossible(ly) & 1 & 0.5 \\
\hline \multirow[t]{6}{*}{ Reliable(ly) } & 1 & 0.8 & Is essential & 1 & 0.5 \\
\hline & & & It is known that/to & 1 & 0.5 \\
\hline & & & Perceive & 1 & 0.5 \\
\hline & & & Reliable(ly) & 1 & 0.5 \\
\hline & & & Well-known & 1 & 0.5 \\
\hline & & & We think & 1 & 0.5 \\
\hline Total & 119 & $100 \%$ & Total & 170 & $100 \%$ \\
\hline
\end{tabular}

Table 6 shows the hedges found in the hard science disciplines corpus. As set out in the table, while the most frequent hedges found in the discussion section of industrial engineering research articles are may $(\mathrm{n}=25)$, indicate $(\mathrm{n}=24)$, suggest $(\mathrm{n}=19)$, seen (as) $(18)$, and most $(\mathrm{n}=15)$, the most frequently employed hedges in mechanical engineering discussion section research articles are may $(\mathrm{n}=47)$, would $(\mathrm{n}=35)$, predication $(\mathrm{n}=34)$, seen (as) $(\mathrm{n}=26)$, predict $(\mathrm{n}=19)$, and could and indicate $(\mathrm{n}=17)$. In general, the findings indicated that the authors of mechanical engineering research articles used more hedges in expressing their stance toward the findings of their own study in the discussion section.

Table 6: Distribution of hedges in hard science discipline research articles.

\begin{tabular}{llllll}
\hline & \multicolumn{3}{c}{ Industrial engineering } & & Mechanical engineering \\
\hline Hedges & $\mathrm{F}$ & $\%$ & Hedges & $\mathrm{F}$ & $\%$ \\
May & 25 & 8.6 & May & 47 & 13.8 \\
Indicate & 24 & 8.3 & Would & 35 & 10.2 \\
Suggest & 19 & 6.5 & Prediction & 34 & 10 \\
Seen(as) & 18 & 6.2 & Seen (as) & 26 & 7.64 \\
Most & 15 & 5.2 & Predict & 19 & 5.5 \\
Should & 14 & 4.8 & Could & 17 & 5 \\
Possible(ly) & 13 & 4.5 & Indicate & 17 & 5 \\
\hline
\end{tabular}


Farnia, Gerami

\begin{tabular}{|c|c|c|c|c|c|}
\hline \multicolumn{3}{|c|}{ Industrial engineering } & \multicolumn{3}{|c|}{ Mechanical engineering } \\
\hline Relatively & 13 & 4.5 & Propose & 16 & 4.7 \\
\hline Likely & 12 & 4.1 & Suggest & 14 & 4.11 \\
\hline Propose & 12 & 4.1 & Most & 9 & 2.64 \\
\hline Would & 12 & 4.1 & Should & 7 & 2 \\
\hline In (general) & 10 & 3.4 & Possible (ly) & 6 & 1.76 \\
\hline Could & 9 & 3.1 & relatively & 6 & 1.76 \\
\hline Seem & 9 & 3.1 & Seem & 6 & 1.76 \\
\hline Appear & 8 & 2.7 & mainly & 5 & 1.47 \\
\hline Around & 6 & 2.0 & Almost & 4 & 1.17 \\
\hline Somewhat & 4 & 1.3 & approximately & 4 & 1.17 \\
\hline Implication & 4 & 1.3 & Consistent with & 4 & 1.17 \\
\hline About & 3 & 1.0 & (in) general & 4 & 1.17 \\
\hline Assume & 3 & 1.0 & About & 3 & 0.88 \\
\hline Consistent with & 3 & 1.0 & Appear & 3 & 0.88 \\
\hline Mainly & 3 & 1.0 & Estimate & 3 & 0.88 \\
\hline Tend & 3 & 1.0 & Generally & 3 & 0.88 \\
\hline Unclear & 3 & 1.0 & ideally & 3 & 0.88 \\
\hline Probability & 3 & 1.0 & quite & 3 & 0.88 \\
\hline Approximately & 2 & 0.69 & Assume & 2 & 0.58 \\
\hline Guess & 2 & 0.69 & assumption & 2 & 0.58 \\
\hline Speculate & 2 & 0.69 & interpret & 2 & 0.58 \\
\hline Suppose & 2 & 0.69 & likely & 2 & 0.58 \\
\hline Often & 2 & 0.69 & perceive & 2 & 0.58 \\
\hline Partially & 2 & 0.69 & probability & 2 & 0.58 \\
\hline Perhaps & 2 & 0.69 & Probable (ly) & 2 & 0.58 \\
\hline Predominantly & 2 & 0.69 & rare (ly) & 2 & 0.58 \\
\hline Quite & 2 & 0.69 & rather & 2 & 0.58 \\
\hline Rather & 2 & 0.69 & Argue & 1 & 0.29 \\
\hline Ideally & 2 & 0.69 & a certain $\mathrm{X}$ & 1 & 0.29 \\
\hline Might & 2 & 0.69 & Apparently & 1 & 0.29 \\
\hline Normally & 2 & 0.69 & Basically & 1 & 0.29 \\
\hline Theoretically & 1 & 0.34 & Essentially & 1 & 0.29 \\
\hline Typically & 1 & 0.34 & Evidently & 1 & 0.29 \\
\hline Uncertain & 1 & 0.34 & frequently & 1 & 0.29 \\
\hline Conjecture & 1 & 0.34 & implication & 1 & 0.29 \\
\hline Unlikely & 1 & 0.34 & imply & 1 & 0.29 \\
\hline Assumption & 1 & 0.34 & Infer & 1 & 0.29 \\
\hline A certain $X$ & 1 & 0.34 & largely & 1 & 0.29 \\
\hline Estimate & 1 & 0.34 & maybe & 1 & 0.29 \\
\hline Possibility & 1 & 0.34 & normally & 1 & 0.29 \\
\hline Prediction & 1 & 0.34 & often & 1 & 0.29 \\
\hline Probable(ly) & 1 & 0.34 & partly & 1 & 0.29 \\
\hline Imply & 1 & 0.34 & perhaps & 1 & 0.29 \\
\hline Frequently & 1 & 0.34 & presumably & 1 & 0.29 \\
\hline Generally & 1 & 0.34 & seemingly & 1 & 0.29 \\
\hline Tendency & 1 & 0.34 & seldom & 1 & 0.29 \\
\hline \multirow[t]{5}{*}{ In theory } & 1 & 0.34 & somewhat & 1 & 0.29 \\
\hline & & & Tend & 1 & 0.29 \\
\hline & & & tendency & 1 & 0.29 \\
\hline & & & typically & 1 & 0.29 \\
\hline & & & usually & 1 & 0.29 \\
\hline Total & 290 & $100 \%$ & Total & 340 & $100 \%$ \\
\hline
\end{tabular}


Comparative Study of Interactional Metadiscourse Markers in the Discussion Section of Soft and Hard Science Research Articles: Hedges and Boosters in Focus

Table 7 shows the boosting words found in the hard discipline corpus. As reported in the table, the most frequent boosters found in industrial engineering research articles are show $(\mathrm{n}=109)$, demonstrate and obviously $(\mathrm{n}=11)$, while the most frequent boosters in the mechanical engineering corpus are show $(\mathrm{n}=78)$, determine $(\mathrm{n}=27)$, and expect $(\mathrm{n}=15)$. The verb show was found to be is the most frequent boosting word in the two corpora.

Table 7: Distribution of boosters in hard discipline research articles.

\begin{tabular}{llllll}
\hline & Industrial engineering & & Mechanical engineering \\
\hline Hedges & $\mathrm{F}$ & $\%$ & Hedges & $\mathrm{F}$ & $\%$ \\
Show & 109 & 53.9 & Show & 78 & 39.5 \\
Demonstrate & 11 & 5.4 & Determine & 27 & 13.7 \\
Obviously & 11 & 5.4 & Expect & 15 & 7.6 \\
Clearly & 8 & 3.9 & Clear(ly) & 8 & 4.0 \\
Determine & 7 & 3.4 & The fact that & 8 & 4.0 \\
Always & 6 & 2.9 & Conclude & 7 & 3.5 \\
Conclude & 4 & 1.9 & Demonstrate & 6 & 3.0 \\
We find & 4 & 1.9 & More than & 6 & 3.0 \\
Confirm & 3 & 1.4 & Obvious (ly) & 5 & 2.5 \\
Perceive & 3 & 1.4 & Particularly & 5 & 2.5 \\
(at) least & 3 & 1.4 & Confirm & 4 & 2.0 \\
Actually & 2 & 0.99 & Always & 3 & 1.5 \\
Indeed & 2 & 0.99 & Reliable(ly) & 3 & 1.5 \\
More than & 2 & 0.99 & Actually & 2 & 1.0 \\
Must & 2 & 0.99 & Indeed & 2 & 1.0 \\
Prove & 2 & 0.99 & Inevitable(ly) & 2 & 1.0 \\
True & 2 & 0.99 & In fact & 2 & 1.0 \\
Is essential & 1 & 0.49 & (at) least & 2 & 1.0 \\
In fact & 1 & 0.49 & Must & 2 & 1.0 \\
Particularly & 1 & 0.49 & Plain(ly) & 2 & 1.0 \\
Precise(ly) & 1 & 0.49 & True & 2 & 1.0 \\
Sure(ly) & 1 & 0.49 & Certainly & 1 & 0.5 \\
The fact that & 1 & 0.49 & Decided(ly) & 1 & 0.5 \\
& & & Evidence & 1 & 0.5 \\
& & & Precise(ly) & 1 & 0.5 \\
& & & Well-known & 1 & 1 \\
\hline Total & & $\mathbf{1 0 0 \%}$ & Total & $\mathbf{1 0 0}$ \\
\hline
\end{tabular}

\section{Discussion}

This study examined the use of hedges and boosters in two disciplines of industrial engineering and mechanical engineering as representatives of hard science, and psychology and management as representatives of soft science in the discussion section of research articles. In response to the first research question, "What are the frequencies of hedges and boosters in the soft and hard science corpora? ", the findings displayed the overuse of hedges as compared to boosters in the two corpora. More precisely, the findings show that authors used $61.15 \%$ and $73.90 \%$ hedges in hard and soft sciences, respectively. In other words, authors in both disciplines prefer to express their discussion with "tentativeness, cautiousness and circumspection on an assertion" (Crismore et al. 1993, cited in Liu and Huang, 2017, 26); this, however, seems to have been more emphasized by writers of soft science discipline research articles (i.e., management and psychology). While creating a discussion based on their 


\section{Farnia, Gerami}

results, these writers seem to prefer to keep their claims provisional, hence creating a room for the readers to express their viewpoints (Ward 2015).

The findings also pointed to the overuse of hedges in soft science research article discussion sections over hard science ones. This is in line with Farrokhi and Emami (2008) who also found a higher frequency of hedges in applied linguistics over electrical engineering. The findings also aligned with Takimoto's (2015) study which revealed a high occurrence of hedges in humanities corpus over natural science. Another finding of the study was that in comparison with the soft science corpus, boosters were overused in the hard science corpus. In other words, hard science writers tend to emphasize force or their certainty in proposition (Hyland, 2004c), and expressing their views more directly than the soft science discipline writers. The findings were in contrast with Kahkesh and Alipour (2017) who reported an overuse of boosters and hedges in the results and discussion sections of literature over engineering research papers, suggesting cross-disciplinary variation in the use of these devices. Moreover, the findings partly replicate those observed by Zarei and Mansoori (2011) and Farrokhi and Emami (2008) which pointed to the high frequency of hedges and boosters in applied linguistics corpus over computer science and electrical engineering research articles. These outcomes confirm Farookhi and Emami's (2008) statement that distribution of these lexical items may be influenced by the norms and practices of particular disciplines.

In order to answer the second research question "Is there any significant cross-disciplinary difference in the use of boosters and hedges?", the findings show that the authors in the soft science disciplines use significantly more hedges compared to the authors in the hard science disciplines. On the other hand, authors of the hard science research articles used significantly more boosters than those of the soft science disciplines. As stated by Takimoto (2015), discourse norms and rhetorical style of each discipline influences the choice of words by writers. Moreover, it speaks to the idea that the authors in the soft sciences tend to be more interpretive and less objective while the authors of hard sciences are more likely fact-oriented and objective (Takimoto 2015).

The findings of this study have some implications for research and teaching EAP classes. As noted by Schmidt (1990), to develop their interlanguage, language learners need some degree of conscious attention to or noticing of the linguistic input (cited in Hyland 2000). Based on this conviction, EAP/ESP teachers are recommended to draw students' attention to the use of these devices through comparison of different research articles, focusing on individual sections. One way to accomplish this is designing tasks which involve finding metadiscourse devices in certain texts and discussing writers' stance over the use of hedges and boosters in the articles. Likewise, EAP/ESP teachers may call students' attention to crosslinguistic variation in the use of metadiscourse markers in learners' first and target languages. According to Crismore, Markkanen, and Steffensen (1993, 42), "comparison of metadiscourse across languages may help explain what causes problems in its use by foreign-language learners." Finally, L2 writing instructors can build on the findings of this and similar studies to help EAP students read more efficiently and write more effective scientific articles. 
Comparative Study of Interactional Metadiscourse Markers in the Discussion Section of Soft and Hard Science Research Articles: Hedges and Boosters in Focus

\section{Conclusion}

This study examined the use of boosters and hedges in the discussion section of research articles in industrial and mechanical engineering as representatives of hard science disciplines and management and psychology as representatives of soft science disciplines. Generally speaking, findings indicated the significant occurrence of hedges in soft discipline and boosters in hard discipline research article discussion sections. It can be concluded that academic writers' discourse is influenced by the norms and rhetorical styles of the disciplines they are writing their articles. The soft sciences are more interpretive while the hard sciences are more objective. Soft science writers tend to invite readers to an open discussion to their findings, while hard science writers leave little room for an open interpretation of the findings.

To arrive at a more comprehensive understanding of the factors influencing the use of these metadiscourse devices, further studies are definitely needed to study other sections of research articles. Moreover, cross-disciplinary comparison of research articles written in native and non-native languages can also provide more insight as to how writers in different languages express their stance in developing their articles. Lastly, a bigger sample size may be selected using corpus tools for analysis. 
Farnia, Gerami

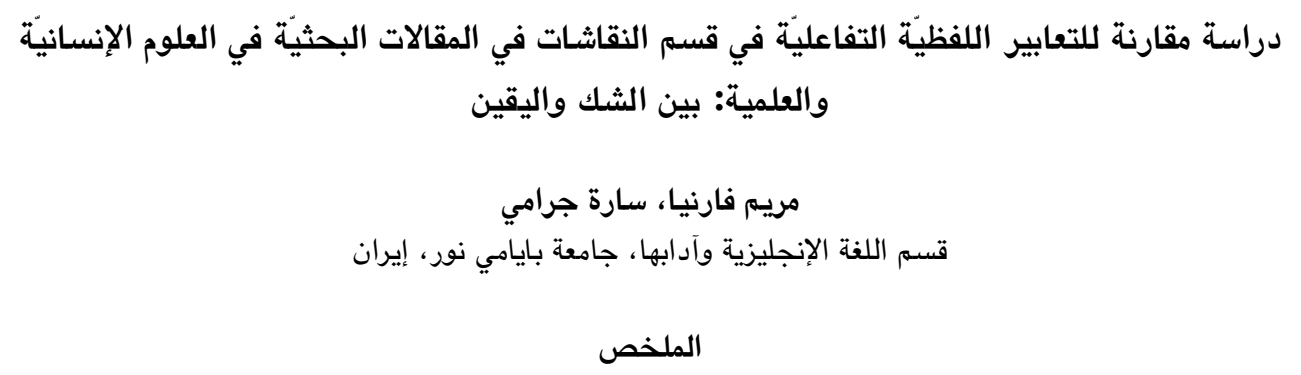

تناول هذا البحث دراسة نوع التعبيرات اللفوية الدالة على التردد أو الثك وتكرارها، وكذلك الألفاظ الدالة على اليقين في أقسام نقاشات المقالات البحثية المنشورة في مجلات العلوم الإنسانية والعلميّة. تم اختيار عينه البحث بشكل عشوائي من المقالات البحثية المنشورة في الهندسة الميكانيكيّة والصناعيّة كتخصصات علميّة والإدارة وعلم النفس كتخصصات علوم إنسانية، وتضمنت الدراسة حوالي سبع عشرة ألف كلمة في كل مجال. أظهرت النتائج أن استخدام تعبيرات التردد أو الثك كان أكثر عند باحثي العلوم الإنسانية، في حين تم الإفراط في استخدام تعبيرات اليقين في الكتابة عند باحثي تخصصات العلوم العلمية، بما يتوافق مع حقيقة أن التخصصات العلمية كونها أكثر موضوعية، ويتم تمثيلها من خلال الاستخدام المتكرر لألفاظ اليقين أكثر؛ وذلك لأنها تعبر عن حقائق علمية. من ناحية أخرى، تتأثر العلوم الإنسانية بذاتيتها الثخصيّة التي تؤدي إلى استخدام أكبر لأسلوب التردد أو الثك كونها مبنيّة على أو تتأثر بالمشاعر الثخصيّة أو الآراء. ويمكن تطبيق نتائج هذه الدراسة في مساقات تدريس اللفة الإنجليزيّة لأغراض خاصة، تترتب نتائج هذه الدراسة بآثار على ممارسة تدريس دورات اللفه الإنكليزية الأكاديميّة EAP ودورات تدريس اللفة الانكليزيّة لأغراض خاصة ESP. الكلمات المفتاحية: قسم المناقشة، بحث علمي، كلمات دلالية، يقين، تردد أو شك. 
Comparative Study of Interactional Metadiscourse Markers in the Discussion Section of Soft and Hard Science Research Articles: Hedges and Boosters in Focus

\section{References}

Alhuqbani, Mohammed Nasser. 2013. Genre-Based Analysis of Arabic Research Article Abstracts across Four Disciplines. Journal of Educational and Social Research 3 (3): 371-382.

Alotaibi, Hmoud. 2015. Metadiscourse in Arabic and English Research Article Abstracts. World Journal of English Language 5 (2): 1-8. http://dx.doi.org/10.5430/wjel.v5n2p1

Aluthman, Ebtisam Saleh. 2018. A cross-disciplinary investigation of textual metadiscourse markers in academic writing, International Journal of Linguistics 10 (2): 19-38. doi:10.5296/ijl.v10i2.12916

Crismore, Avon, Raija Markkanen, and Margaret S. Steffensen. 1993. Metadiscourse in Persuasive Writing: A Study of Texts Written By American and Finnish University Students. Written Communication 10 (1): 39-71. doi: 10.1177/0741088393010001002

Farnia, Maryam, Masoud Saeedi, and Zahra Ataei. 2020. A Cross-Disciplinary Study on Evaluative Strategies in Research Articles Conclusion Sections. International Journal of Research in Education 5 (1): $1-18$

Farrokhi, Farahman and Safoora Emami. 2008. Hedges and Boosters in Academic Writing: Native vs. Non-Native Research Articles In Applied Linguistics and Engineering. Journal of Applied Linguistics 1 (2): 62-98.

Farzannia, Sara, and Maryam Farnia. 2016. Metadiscourse Markers in Introduction Sections of Persian and English Mining Engineering Articles. English for Specific Purposes World 49 (17): 1-16.

Fu, Xiaoli, and Ken Hyland. 2014. Interaction in two journalistic genres: A study of interactional metadiscourse. English Text Construction 7 (1): 122-144.

Halliday, Michael. 1994. An introduction to functional grammar (2 $2^{\text {nd }}$ ed.). London: Edward Arnold.

Hashemi, Mohammad R. and Iman Gohari Moghaddam. 2016. A Mixed Methods Genre Analysis of the Discussion Section of MMR Articles in Applied Linguistics. Journal of Mixed-Method Research: 119. doi: https://doi.org/10.1177/1558689816674626

Holmes, Janet. 1990. Hedges and boosters in women's and men's speech. Language and communication 10 (3): 185-205. https://doi.org/10.1016/0271-5309(90)90002-S

Hu, Guangwei, and Feng Cao. 2011. Hedging and boosting in abstracts of applied linguistics articles: A comparative study of English- and Chinese-medium journals. Journal of Pragmatics 43 (11): 27952809. https://doi.org/10.1016/j.pragma.2011.04.007

Hunston, Susan, and Geoff Thompson. 2001. Evaluation in Text. Oxford: Oxford University Press.

Hyland, Ken. 1998. Boosting, Hedging and the Negotiation of Academic Knowledge. Texts 18 (3): 349 382. 
Farnia, Gerami

Hyland, Ken. 2000. Hedges, Boosters and Lexical Invisibility: Noticing Modifiers in Academic Texts. Language Awareness 9 (4): 179-197.

Hyland, Ken. 2004a. Genre and Second Language Writing. Ann Arbor: University of Michigan Press.

Hyland, Ken. 2004b. Disciplinary interactions: metadiscourse in L2 postgraduate writing. Journal of Second Language Writing. 13: 133-151.

Hyland, Ken. 2004c. Disciplinary discourses: Social Interactions in Academic Writing. Ann Arbor MI: University of Michigan Press

Hyland, Ken. 2005. Metadiscourse: Exploring Interaction in Writing. London: Continuum.

Hyland, Ken and Polly Tse. 2004. Metadiscourse in Academic Writing: A Reappraisal. Applied Linguistics 25 (2): 156-77.

Hyland, Ken. 2013. Writing in the University: Education, Knowledge and Reputation. Language Teaching 46 (1): 53-70. doi: https://doi.org/10.1017/S0261444811000036

Hyland, Ken. 2015. Metadiscourse. In Tracy, K. (ed.) International Encyclopedia of Language and Social Interaction. Oxford: Wiley-Blackwell

Hyland, Ken, and Feng (Kevin) Jiang. 2020. Text-organizing Metadiscourse: Tracking Changes in Rhetorical Persuasion. Journal of Historical Pragmatics 21 (1): 137-164.

Kahkesh, Maryam, and Mohammad Alipour. 2017. A comparative Analysis of Metadiscourse Markers in the Result and Discussion Sections of Literature and Engineering Research Papers. Iranian Journal of Applied Language Studies 9: 71-82.

Karimi, Keihaneh, Maryam Maleki and Maryam Farnia. 2017. Metadiscourse Markers in the Abstract Sections of Persian and English Law Articles. International Journal of Foreign Language Teaching and Research (IJFLTR) 5 (18): 69-83.

Khedri, Mohsen, Chan Swee Heng and Tan Bee Hoon. 2013. Cross-Disciplinary and Cross-Linguistic Perspectives on Metadiscourse in Academic Writing. Southern African Linguistics and Applied Language Studies 31 (1): 129-138, doi: 10.2989/16073614.2013.793957

Kim, Loi Chek, and Jason Miin-Hwa Lim. 2013. Metadiscourse in English and Chinese Research Article Introductions. Discourse Studies 15 (2): 129-146. https://www.jstor.org/stable/24443317

Lee, Joseph, and J. Elliott Casal. 2014. Metadiscourse in Results and Discussion Chapters: A CrossLinguistic Analysis of English and Spanish Thesis Writers in Engineering. System 46: 39-54. https://doi.org/10.1016/j.system.2014.07.009

Li, Zhijun, and Jinfen Xu. 2020. Reflexive Metadiscourse in Chinese and English Sociology Research Article Introductions and Discussions. Journal of Pragmatics 159: 47-59, https://doi.org/10.101 6/j.pragma.2020.02.003

Liu, Ping, and Xu Huang. 2017. A Study of Interactional Metadiscourse in English Abstracts Of Chinese Economics Research Articles. Higher Education Studies 7 (3): 25-41. http://doi.org/10.5539 /hes.v7n3p25 
Comparative Study of Interactional Metadiscourse Markers in the Discussion Section of Soft and Hard Science Research Articles: Hedges and Boosters in Focus

Markkanen, Raija, and Hartmut Schröder. 1997. Hedging: A challenge for pragmatics and discourse analysis. In Raija Markkanen \& Hartmut Schröder (eds.), Hedging and discourse: Approaches to the analysis of a Pragmatic phenomenon in academic texts (pp. 3-18). Berlin: Walter de Gruyter.

Martin, J. R. 2001. Beyond exchange: Appraisal systems in English. In S. Hunston and G. Thompson (Eds.). Evaluation in text (pp. 142-175). Oxford: Oxford Placement Test

Mu, Congjun, Lawrence Jun Zhang, John Ehrich, and Huaqing Hong. 2015. The use of metadiscourse for knowledge construction in Chinese and English research articles. Journal of English for Academic Purposes 20: 135-148. https://doi.org/10.1016/j.jeap.2015.09.003

Parkinson, Jean. 2011. The discussion section as argument: The language used to prove knowledge claims. English for Specific Purposes 30 (3): 164-175. http://dx.doi.org/10.1016/j.esp.2011.03.001

Schmidt, Richard W. 1990. The role of consciousness in second language learning. Applied Linguistics, 11 (2): 17-46. https://doi.org/10.1093/applin/11.2.129

Sedaghat, Azam., Reza Biria, and Yaghoub Asadi Amirabadi. 2015. Cross cultural analysis of hedges in Persian and English editorial columns. International Journal of Language Learning and Applied Linguistics World 8 (1): 37-50.

Siami, Tohid and Reza Abdi. 2012. Metadiscourse strategies in Persian research articles; Implications for teaching writing English articles. Journal of English Language Teaching and Learning 9: 165-176.

Sorahi, Mohammadamin, and Mansour Shabani. 2016. Metadiscourse in Persian and English research article introductions. Theory and Practice in Language Studies 6 (6): 1175-1182. http://dx.doi.org/10.17507/tpls.0606.06

Sultan, Abbas H.J. 2011. A contrastive study of metadiscourse in English and Arabic linguistics research articles. Acta Linguistica 5 (1): 28-41.

Swales, John, and Christine Feak, 2004. Academic writing for graduate students: Essential tasks and skills (2nd ed.). Ann Arbor: University of Michigan Press.

Takimoto, Masahiro. 2015. A corpus-based analysis of hedges and boosters in English academic articles. Indonesian Journal of Applied Linguistics 5 (1): 95-105. https://doi.org/10.17509/ijal.v5i1.836

Uba, Sani Yantandu. 2020. Metadiscourse in research article genre: A cross-linguistic study of English and Hausa, English Language Teaching 13 (2): 57-62. doi: 10.5539/elt.v13n2p57

Vande Kopple, Willian J. 1985. Some exploratory discourse on metadiscourse. College Composition and Communication 36: 1-27.

Ward, Holly Vass. 2015. A comparative analysis of hedging in a corpus of two written legal discourse genres. Doctoral Thesis. Licenciada en Filologia Hispanica. Retrieved from: http://oa.upm.es/39087/1/HOLLY_VASS_WARD.pdf

Wei, Jing, and Jing Duan. 2019. A comparative study of metadiscoursal features in English research article abstracts in hard disciplines, Arab Journal of Applied Linguistics 4 (1): 1-37

Yazdani, Sara, Shahla Sharifi, and Mahmoud Elyassi. 2014. Interactional metadiscourse in English and Persian news articles about 9/11. Theory and Practice in Language Studies 4 (2): 428-434. http://dx.doi.org/10.4304/tpls.4.2.428-434 


\section{Farnia, Gerami}

Zarei, Golamreza, and Sara Mansoori. 2011. A contrastive study on metadiscourse elements used in humanities vs. non humanities across Persian and English. English Language Teaching 4 (1): 42-50.. 